\title{
Economic Growth in Nigeria: Evidence from the Appraisal of Financial Sector Reforms and its Causal Effects.
}

\author{
${ }^{1}$ Manasseh, Charles Osondu, ${ }^{2}$ Asogwa, Fredrick Onyebuchi (PhD); ${ }^{3}$ Agu, David \\ Onyinyechi and Aneke, Gladys. C. (PhD) \\ ${ }^{1,2,3,4}$ Department of Economics, University of Nigeria, Nsukka. Enugu State, South-East Nigeria. West Africa.
}

\begin{abstract}
The growth of financial system, as the central hub of every economy is paramount for economic development. The reformation of the financial sector is the bedrock for building a formidable, transparent and efficient financial system that could supports the mobilisation of domestic and foreign savings for investment. Conversely, it deepens and broadens financial intermediation, and enforces strict regulations with prudential guide for increase in business activities. Thus, the aim of the study is to investigate the causal relationship between financial sector reforms and economic growth in Nigeria. The study also established the impact of financial sector reforms on economic growth to ascertain if financial sector reforms in Nigeria promote growth. To establish this, financial sector reforms is measured with the ratio of banking sector domestic credit, domestic credit to the private sector and Capital flow proxied with foreign direct investment while economic growth is captured with Per capita GDP. Using generalised linear regression method, with quarterly time series data that spans the periods 1981Q1 to 2010Q4, the following findings on granger causality test were noticed; (a) bidirectional relationship between banking sector domestic credit and per-capita GDP; (b) unidirectional causation running from foreign direct investment to per-capita GDP and; (c) unidirectional causation running from per-capita GDP to domestic credit to the private sector. However, from the findings, banking sector domestic credit and foreign direct investment are the major policy variables that can be adjusted for economic growth. Finally, the estimated regression results show that the explanatory variables accounted for approximately 63.45 percent variation in economic growth. Hence, financial sector reform promotes economic growth in Nigeria.
\end{abstract}

GEL Classification: G10.

Keyword: Development, Reforms, Causality, Bidirectional, Unidirectional, Financial Sector.

\section{Introduction:}

Owing to the government-led-development paradigm of dominating the economy without much regard to the private sector before 1986 in Nigeria, the ugly consequences of excruciating external debt burden, high rate of unemployment, sharp fall in term of trade, low growth rate, low per-capita income and abject poverty etc has becomes an issue of discourse. To this, there was an urgent call for a rethink on the underlying philosophy of the Nigerian economic development which gave birth to 1986 Structural Adjustment Programme (SAP) deregulation policy reform. This reform aimed at promoting private sector led development in order to reduce over dependency on oil sector, the dominance of unproductive investment in the public sector and to enhance the growth potential of the private sector and economic growth. However, prior to the deregulation policy reforms of the economy, the Nigerian financial sector, largely dominated by banking industry have been the most regulated because of its inefficiency and expected pivotal role in enhancing investment, such as identifying and funding good business opportunities, mobilisation of savings and risks diversifications, facilitation of exchange of goods and services that could result to a more efficient allocation of resources, rapid accumulation of physical and human capital, and faster technological progress (Adegbite, 2005 and Adelakun, 2010).

It is a clear fact that an organized, developed and efficient financial system provides individuals and corporate investors with an additional financial instrument that can stimulates the quality of transactions and investments in the country (Manasseh, et.al 2012). Be that as it may, it could be said that, developed and efficient financial market is an embodiment of healthy financial sector reforms. This is because, the primary aim of most of the financial reforms among emerging economies of the world lies on the attainment of economic growth which mostly dwells on a viable macroeconomic environment and property right of the investors, geared towards creating a friendly and competitive business environment that can promote the level of confidence, financial soundness and economic growth.

Before 1986 consolidation policy reforms, the Nigerian stock market was nothing to ride home about given the poor rating and performance of the market. A year after or there about, the market took a different 
direction. Even though, the market was a bit better compare to its performance prior to the reforms, the problem of bank failure and financial distress became the order of the day. Between 1994 and 2000, a total of about 35 financial institutions' licenses were revoked by the Central Bank of Nigeria (CBN); and the Nigeria Deposit Insurance Corporation (NDIC) was ordered by the Federal High Court of Nigeria to liquidate the said institutions (http://www.ndic.org.ng/closed-financial-institutions.htm). Hence, this became an issue of concern to the policy makers. In 2004, the Central Bank of Nigeria under the Governorship of Prof. Soludo Chukwuma came up with a consolidation policy reform that was meant to raise the minimum capital base of banks from N2 billion to N25 billion so as to curb the persistent occurrence of bank liquidation and loss of depositors funds (Agu and Manasseh, 2012). However, the outcome of the reform saw to a dramatic reduction in the numbers of Banks from about 89 to 25 in 2005 then later reduced to 24. Hence, after 2006 post consolidation policy reforms, the number of banks further reduced to about 16, thus causing an upward trend in the market indices like capitalisation and total values of all shares traded, as shown in figure 1 below.

Figure 1: Plot of Total Values of Shares Traded (Tvst) and Market Carpitalisation (Mc):

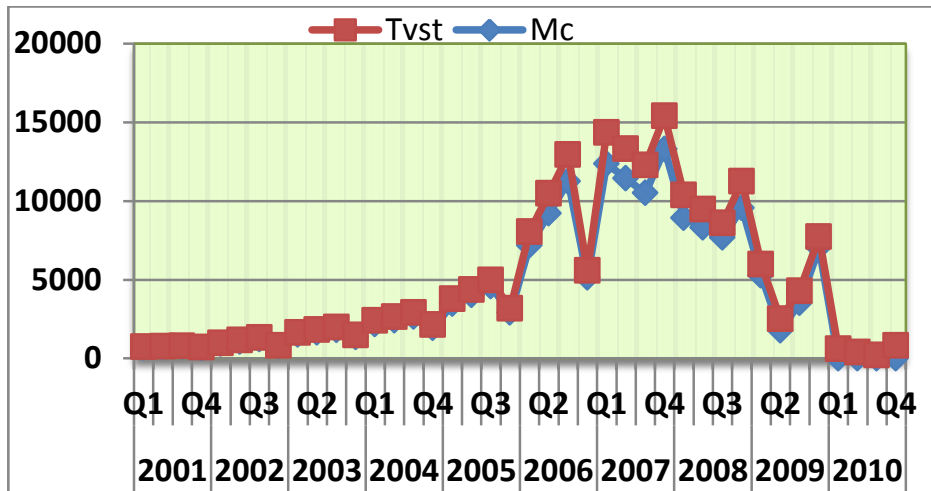

Market carpitalisation for the first time exceeded N2.5 trillion with more than N2 billion worth of total shares traded in 2005. After 2005, The indices maintained a steady trend on the increasing lane up to 2007 when market capitalization and values of shares traded reached a peak of about N13.295 trillion and N2.1 trillion respectively (ibdi). In like manner, the share of the banking sector rose from 34.4 percent of total market capitalization in 2004 to 41.8 percent in 2006. In addition, between 2004 and 2006 banking sector capitalization grew by 223 percent. This implies that the share of the banking sector in the market grew alongside the growth of the entire market. In fact, over 46 percent of the total growth in market capitalization came from the growth in banking sector alone (Agu, 2011).

In the same vein, the pension industry also went through a major reform, triggered by the enactment of the Pension Reform Act in 2004 which transformed the pension industry. According to the study by Gunu and Tsado (2012), Pension Fund Investments in domestic quoted equities amounted to N240.38 billion (2.36\% of total market capitalization) in 2007, 3.17\% in 2008, 4.42\% in 2009 and 4.53\% in 2010, also the value of total Pension Fund Assets stood at N2, 029 billion as at 2010 while Ahmad (2012) claimed that pension (\% of GDP) has grown from 1.5 per cent in 2006 to about 8.5 per cent by December 2011. The Insurance sector also went through a process of reforms somewhat similar to the recapitalization of the banking sector. The recapitalization and consolidation exercise in the insurance sector led to the emergence of 49 recapitalized insurance companies out of the 104 that existed before the consolidation. The landmark reforms in the banking, insurance and pension sectors transformed the Nigerian capital market, resulting in an unprecedented growth (CBN, 2009). To the greatest dismay, in overall, the reform, which brought about growth in the Nigerian financial sector, fails to make an increased contribution to Nigeria's GDP. For instance, between 2003 and 2008, total bank assets increased from N3.05trillion to about N16 trillion at the close of 2008. Between 2003 and 2007, market capitalization increased from N1.35 trillion to N13.295 trillion while the contribution of financial sector to GDP declined from $4.23 \%$ in 2003 to $3.86 \%$ in 2007 (CBN, 2009). Thus, the disconnection between the financial sector and Nigerian economic growth deposited a question "why" in the minds of every Nigerians.

In view of the above, studies have shown that the ability of the financial sector to play its role of accelerating economic growth has been punctuated by its vulnerability to systemic distress, insecurity, unfriendly business environment, weak institutional and regulatory framework, uneven supervision and enforcement, inadequate disclosure and transparency about the financial position of banks, lack of investor and consumer sophistication (Sanisu, 2012 and Kama, 2006). Also, the ugly trend of inaptitude behaviour of the authorities, high level of corruptions and massive pursuit of individual interest have always question the relevance of the sector as a veritable tool to promote growth in the Nigerian economy (Manasseh et.al, 2012). 
Despite these challenges that had been surmounted through series of reforms undertaken by Central Bank of Nigeria $(\mathrm{CBN})$ in the recent past, the present CBN Governor, Dr Sanusi Lamido pointed the need for periodic reforms in the financial sector in order to foster financial stability and confidence in the system but with particular emphasis on the banking industries because of its contribution of over 46 percent of the total growth in market capitalization. Recently, $\mathrm{CBN}$ articulated a blue print known as "The Project Alpha Initiative" for reforming the Nigerian financial system in general and the banking sector in particular. The reforms aimed at removing the inherent weaknesses and fragmentation of the financial system. In 2010, the Asset Management Corporation of Nigeria (AMCON) was established following the promulgation of its enabling Act by the National Assembly aimed at addressing the problem of non-performing loans in the Nigerian banking industry, among others. To further reduce the high level of corruption in the system and engender public confidence in the banking system and enhance customer protection, the CBN established the Consumer and Financial Protection Division to provide a platform through which consumers can seek redress. Another land mark was the introduction of the non-interest banking in Nigeria (e.g. Jaiz Bank Plc.) and Cash less Policy as part of ongoing reforms to address currency management challenges in Nigeria (Sanusi, 2012). Therefore, considering the newly introduced practices and the ongoing policy reforms in the sector to address the challenges, this study intend to provide a preliminary evidence on the relative importance of financial sector reforms on economic growth and also, investigate the causal relationship between financial sector reforms and economic growth in Nigeria.

\section{Research Questions:}

a. Does a financial sector reform promote economic growth in Nigeria?

b. Is there any causal relationship between financial sector reform and economic growth in Nigeria?

\section{Objective of the Study:}

The overall objective is to examine financial sector reforms promote economic growth in Nigeria. Specifically, the study intends to;

a. Examine if financial sector reforms promotes economic growth.

b. Investigate the causal relationship between financial sector reform and economic growth in Nigeria.

\section{Hypothesis of the Study:}

The null hypotheses of the study are as follows;

a. Financial sector reform does not promotes economic growth in Nigeria

b. There is no causal relationship between financial sector reform and economic growth in Nigeria.

\section{Motivation for the study:}

Given the enormous body of evidence on financial sector development and economic growth, no single research to the best of our knowledge had constituted an in-depth study on the causal relationship between financial sector reforms and economic growth in Nigeria accept Manasseh et.al (2012) which emphasis more on stock market development and economic growth with integration of the influence of financial sector reforms on stock market development while Odeniran and Udeaja (2010) study on financial sector development and economic growth tests the competing finance-growth nexus hypothesis. Both studies employed Vector autoregressive method (VAR). Thus, our study emphasis on the relevance of reforms in financial sector and its implications on economic growth using generalized linear regression method. We also employed granger causality test to trace the nature of causal relationship between the financial sector reform and economic growth. Hence, this paper is divided into five sections. Section two is a review of literature, Section three outlines the methodology, and Section four discusses the empirical findings while section five is the conclusion and policy suggestions.

\section{Theoretical Literature:}

\section{Review of Literature:}

There has been a serious debate on the link between financial sector development and economic growth among different schools of thought. The first school "supply leading" is of the view that financial development may lead to growth in that a well developed financial system performs several critical functions to enhance the efficiency of intermediation namely by reducing information asymmetry, transaction, and monitoring costs (McKinnon, 1973; King and Levine 1993; Schumpeter 1912 and Shaw, 1973). For example, Creane et.al (2003) argued that a modern and efficient financial system mobilizes savings, promotes investment by identifying and funding good business opportunities, monitors the performance of managers, enables the trading, hedging, and diversification of risk, and facilitates the exchange of goods and services. These functions ultimately result in a more efficient allocation of resources, a more rapid accumulation of human and physical capital, and in faster 
technological progress, which in turn feed economic growth (Boopen et.al, Nil). Bencivenga, et.al. (1996) and Levine (1998) argued that financial market liquidity plays a key role in economic growth by providing assets to savers that are easily liquidated at any time while simultaneously allowing firms permanent access to capital that are raised through equity issues.

McKinnon (1973) and Shaw (1973) contend that the financial sector development can be the major driver of economic growth if it can only be relieved of its own fetters. They argued that when a financial sector is repressed then it can only respond passively to the real-sector needs. Also, studies by Levine and Zervos (1998), Schumpeter (1934) and Hossain and Kamal (2010) conformed to this school in their studies. They demonstrated that financial development is a prerequisite condition for growth even though, Stiglitz (1994) pointed out strongly that the development of the markets can be detrimental to economic growth by encouraging counterproductive corporate takeovers and promote short-term profits which do not accord corporate managers a chance to focus on the long-term prospects of investment. However, this school of thought was sub divided into Structuralists and Repressionists. The Structuralists are of the view that the quantity and the composition of financial variables induce economic growth by directly increasing savings in the form of financial assets, thereby spawning capital formation and economic growth. The Repressionists on the other hand contend that financial liberalisation in the form of an appropriate positive real rate of return on real cash balances is a vehicle for promoting economic growth. Hence, a liberaised financial system causes an increase in saving and investment.

The second school of thought called "the demand-following" argued that financial development follows economic growth. As the economy expands its demand for certain financial instruments increases which in turn lead to financial market development. For example, Gurley and Shaw (1960) and Gelb (1989), argued that the causal relationship runs from growth to financial deepening, and that the demand for financial services increases with economic development. Singh (1999) also postulated that financial development does not in any way lead to long run economic growth due to macroeconomic instability, volatility and arbitrariness of pricing process; and that instead the macroeconomic activities have an upper hand in the interaction between the two variables. He pointed that as the economy expands, the demand for certain financial instruments increases, leading to the growth of these services and the end result is that the developments in macroeconomic activity influences on the financial market development.

The third school of thought contends that there is bi-directional causality between financial market development and economic growth. A country with a well developed financial system could promote high economic expansion through technological changes, products and services innovation. This will in turn create a high demand for the financial institutions. As the financial institutions effectively respond to this demand, these changes will stimulate higher economic achievement. Both financial market development and economic growth are therefore positively interdependent and their relationship could lead to bidirectional causality (Majid, 2007). Also Dawson (2008) contends that there exists a bi-directional causality, from financial market and economic development, and from economic development to financial market. Therefore, a country with a well developed financial system, can promote high economic expansion through technological changes, products and services innovation. This would in turn create a high demand for the financial institutions, and as the financial institutions effectively respond to this demand, these changes will stimulate higher economic development.

The fourth school of thought supported by Mazur and Alexander (2001) referred to as the independent hypothesis, argued that financial market development and economic growth is not causally related.

\section{Related Empirical Literature:}

In Nigeria, various studies have tried to investigate the nature of relationship that exists between financial development and economic growth and such studies Ogujiuba and Obiechina (2011); Odenira and Udeaja (2010); Egbetunde and Mobolaji (2010); Akinlo and Egbetunde (2010); Quartey (2008); Majid (2008); Dawson (2008) and Odhiambo (2005); Ndebbio (2004); Nzotta and Okereke (2009); Afangideh (2009); Agu and Chukwu (2008) and Manasseh et.al (2012) etc. Majid (2008) empirically examines the short and long run financial growth nexus during post 1997 financial crises in Malaysia. Based on the $(2,1,2,1)$ model, the study documented a long run equilibrium between economic growth, financial depth and inflation. Granger causality test based on VECM further reveals that there is a unidirectional causality running from financial development to economic growth in Malaysia.

Odhiambo (2005) examines the dynamic causal relationship on the role of financial development on economic growth in Tanzania. The study uses three proxies of financial development against real GDP per capita (a proxy for economic growth). Using the Johansen-Juselius cointegration method and vector errorcorrection mechanism, the empirical results of this study, taken together, reveal bidirectional causality between financial development and economic growth in Tanzania - although a supply-leading response tends to predominate. When the ratio of broad money to GDP (M2/GDP) is used, a distinct supply-leading response is found to prevail. However, when the ratio of currency to narrow definition of money (CC/M1) and the ratio of 
bank claims on the private sector to GDP (DCP/GDP) are used, bi-directional causality evidence seems to prevail. The study therefore recommends that the current financial development in Tanzania be developed further in order to make the economy more monetized. Odhiambo (2008) also extended his analytical skill on the same topic but with a particular interest in South Africa economy using the newly developed ARDL-Bounds testing procedure. He had almost the same result in Tanzania but the difference in his findings suggest that the causal flow from stock market development to economic growth in South Africa predominates unlike his study in Tanzania. Odhiambo (2008) examines the direction of causality between financial development and economic growth in Kenya using a dynamic Granger causality model. The study has been motivated by the current debate on the inter-temporal causal relationship between financial development and economic growth in developing countries. The thrust of this debate has been whether there exists a finance-led growth response or a growth-led finance response between the two variables. To this end the study uses three proxies of financial development against real GDP per capita (a proxy for economic growth). The empirical results reveal that, although the causality between financial development and economic growth in Kenya is sensitive to the choice of measure for financial development, on balance the demand following response tends to predominate. The study, therefore, concludes that the argument that financial development unambiguously leads to economic growth can only be taken with a pinch of salt.

Akinlo et.al (2010) examines the long run and causal relationship between financial development and economic growth for ten countries in sub-Saharan Africa. Using the vector error correction model (VECM), the study finds that financial development is cointegrated with economic growth in the selected ten countries in subSaharan Africa. It shows a long run relationship between financial development and economic growth in the selected sub-Saharan African countries. The results show that financial development Granger causes economic growth in Central African Republic, Congo Republic, Gabon, and Nigeria while economic growth Granger causes financial development in Zambia. However, bidirectional relationship between financial development and economic growth was found in Kenya, Chad, South Africa, Sierra Leone and Swaziland.

In the same vein, Egbetunde and Mobolaji (2010) attempted to examine the long run and causal relationship between financial development and economic growth for ten countries in sub- Sahara Africa, using VECM. Their findings suggest that financial development cointegrate with economic growth in all selected ten countries in the region. Granger causality based on multivariance vector error correction (VECM) further shows that financial development granger causes economic growth in Nigeria, Burundi, Cameroon and Mali while economic growth granger causes financial development in Benin, Bukina Faso, Madagascar and Malawi. The evidence also shows bidirectional causality between financial development and economic growth in Cote d'lvoire and Ghana. Base on these result, the study argues that financial development promote economic growth in Nigeria, Burundi, Cameroon and Mali while economic growth promote financial development in Benin, Bukina Faso, Madagascar and Malawi and the two remaining countries' financial development and economic growth are interdependent. Odeniran and Udeaja (2010) findings demonstrated a bidirectional causality between ratios of broad money stock to GDP, growth in net domestic credit to GDP, growth in private sector credit to GDP and growth in banks deposit liability to GDP as proxies for financial development and economic growth variable in their study on financial sector development and economic growth, using Granger causality tests in a VAR framework over the period 1960-2009. Specifically, they found that the various measures of financial development granger cause output even at 1per cent level of significance with the exception of ratio of broad money to GDP. Also, net domestic credit is equally driven by growth in output. The variance decomposition shows that the share of deposit liability in the total variations of net domestic credit is negligible, indicating that shock to deposit does not significantly affect net domestic credit.

Olofin and Afangideh (2008) investigate the role of financial structure in economic development in Nigeria using aggregate annual data from 1970 to 2005. The study developed a small macroeconomic model to capture the interrelationships among aggregate bank credit activities, investment behavior and economic growth given financial structure of the economy, the study holds that a developed financial structure has no independent effect on output growth through bank credit and investment activities, but financial sector development merely allows these activities to positively respond to growth in output.

Odenira and Udeaja (2010) examine the relationship between financial sector development and economic growth in Nigeria. It tests the competing finance-growth nexus hypothesis using Granger causality tests in a VAR framework over the period 1960-2009. Four variables, namely; ratios of broad money stock to GDP, growth in net domestic credit to GDP, growth in private sector credit to GDP and growth in banks deposit liability to GDP were used to proxy financial sector development. The empirical results suggest bidirectional causality between some of the proxies of financial development and economic growth variable. Specifically, we find that the various measures of financial development granger cause output even at 1per cent level of significance with the exception of ratio of broad money to GDP. Additionally, we find that net domestic credit is equally driven by growth in output, thus indicating bidirectional causality. The variance decomposition shows that the share of deposit liability in the total variations of net domestic credit is negligible, indicating that shock 
Economic Growth in Nigeria: Evidence from Financial Sector Reform - the appraisal of its ....

to deposit does not significantly affect net domestic credit. The findings from the paper indicate that the current reforms in the Nigerian banking sector should not be emphasized unilaterally. Rather, attention should be given to the complimentary and coordinated development of financial reforms and changes in the real sector of the economy.

Ndebbio (2004), using an ordinary least square regression framework, finds that financial sector development weakly affect per capita growth of output. He attributed the result to shallow finance and the absence of well functioning capital markets. The finding of Nnanna (2004) was more disturbing. He, also using ordinary least square regression technique, concluded that financial sector development did not significantly affect per capita growth of output. Similarly, Nzotta and Okereke (2009), based on two stages least analytical framework for a period starting from 1986 t0 2007, concluded that financial deepening did not support economic growth in Nigeria. However, Afangideh (2009), using three stage least square estimation technique on a data spanning 1970 to 2005 , found that a developed financial system alleviates growth financing constraints by increasing bank credit and investment activities with resultant rise in output. The finding of Agu and Chukwu (2008) is quite different from other authors on Nigeria. They employed the augmented Granger causality and Toda Yamamoto test to ascertain the direction of causality between financial deepening and economic growth in Nigeria between 1970 and 2005. Their findings revealed evidence to support both demand- and supply-leading hypotheses, depending on the financial deepening variable that is used. In addition to the existing literature on finance and economic growth, this study sets to investigate the path of finance-growth nexus in Nigeria.

Manasseh et.al, (2012) study investigate the causal link between stock market development, financial sector reform and economic growth in Nigerian using time series econometric method of vector autoregressive (VAR) model of Sim (1980) and error correction model (VECM). The study used quarterly time series data which covered the period 1981Q1 to 2010Q4. Their findings suggest a positive long run relationship between the variables of cointegrating equations. In addition, they discover a bidirectional causality existing between stock market development and economic growth which suggest that economic growth and the market development promote each other. Furthermore, they equally found a bidirectional relationship between financial sector reform and economic growth.

Adelakun (2010) empirically examines the relationship between financial development and economic growth. In his study, the perceived relationship between financial development and economic growth is estimated econometrically using the Ordinary Least Square Estimation Method (OLSEM). The result showed that there is a substantial positive effect of financial development on economic growth in Nigeria. The Granger causality test showed that financial development promotes economic growth, but there is evidence of causality from economic growth to the development of financial intermediaries.

Ogujiuba and Obiechina (2011) adopt an empirical review approach for its analysis. Their paper suggests therefore, that the present reforms be reviewed and sustained in an orderly manner, for appropriate channeling of resources for investment and productive purposes. Efforts should be concentrated on the linkages of the sector with macro accounts and where financial development appears to have been the weakest. Furthermore, advancement of the financial sector vis-à-vis instruments should be the primary focus for the authorities. A counterfactual feedback mechanism should also be integrated within the financial sector for an appropriate signaling for the economic productive base.

\section{Model, Data and Methodological Framework:}

The theoretical underpinning of the study lies on the work of McKinnon, 1973; King and Levine 1993; Schumpeter 1912 and Shaw, 1973 which assert that financial development promote economic growth. Generalised linear regression model is used alongside with granger causality test to ascertain the direction of causation between financial sector reforms and economic growth in Nigeria. We used quarterly time series data which cover the period between 1981Q1 to 2010Q4. The data was extracted from World Development Indicator database and Central Bank of Nigeria Statistical bulletin.

$$
E D_{t}=\lambda_{0}+\lambda_{1} F s r_{t}+\lambda_{2} M l q d t y_{t}+\lambda_{3} B e n v_{t}+v_{t}----------------------------(1)
$$

Where; $F s r_{t}$, Mlqdty and $_{\mathrm{B}} \mathrm{Benv}_{\mathrm{t}}$ in model are vectors of financial sector reforms, market liquidity and business environment. $\mathrm{Fsr}_{\mathrm{t}}$ is measured with domestic credit to the private sector as percentage of GDP (DctpsPGDP), domestic credit from banking sector (BsDcPGDP) as percentage of GDP and Capital flow proxied with Foreign Direct Investment (Fdi). Market liquidity is measured with value of shares traded and turnover ratio while Benv $v_{t}$ is captured with Gross Domestic Private Investment (Gdopinv) proxied with gross fixed capital formation (Gfcf) while $\mathrm{ED}_{\mathrm{t}}$ is economic development captured with GDP per capita - GdpPcap (constant LCU). $\lambda_{0}$ and $v_{t}$ are the intercept and the error term respectively. Thus, the second model is specified as indicated in equation 2 below: 
Economic Growth in Nigeria: Evidence from Financial Sector Reform-the appraisal of its ....

$G d p P c a p_{t}=\lambda_{0}+\lambda_{1} D c t p s P G D P_{t}+\lambda_{2} B s D c P G D P_{t}+\lambda_{3} F D I_{t}+\lambda_{4} G f c f_{t}+\lambda_{5} T v s t_{t}+\lambda_{6}$ Tor $_{t}+v_{t}$

We included business environment in the model to check if conducive environment such as accessible road, steady power supply, security, property right, shareholders protection, strong legal framework, macroeconomic stability etc have any significant impact on economic development. However, business environment captured with Gross Domestic Private Investment (Gdopinv) is proxied with gross fixed capital formation (Gfcf). Hence, improvement in business environment should promote growth in gross fixed capital formation. Since development in the financial sector is a prerequisite of the past and ongoing reforms, we may conclude that without reforms there will be no financial development. Thus a developed financial sector should be able to promote the private sector which is the moving trend for economic growth and development. Therefore, factors that determine financial development should also be influenced by reforms within the sector. Be that as it may, we captured financial sector reform or financial sector development with domestic to private sector as \% GDP - DctpsPGDP; domestic credit from the banking industry as \% of GDP - BsDcPGDP and gross domestic private investment proxied by foreign direct investment. According to World Bank, Domestic credit provided by the banking sector includes all credit to various sectors on a gross basis, with the exception of credit to the central government. The banking sector includes monetary authorities and deposit money banks, as well as other banking institutions - savings and mortgage loan institutions and building and loan associations. Domestic credit to private sector refers to financial resources provided to the private sector through loans, purchase of non equity securities, trade credits and other account receivable that establish a claim for repayment. Foreign direct investment into Nigeria by a foreign company either by buying a company in the country or by expanding operations on already existing business in the country.

\section{Transformation of equation 2:}

${\log G d p P c a p_{t}}_{1}=\lambda_{0}+\lambda_{1} \log D c t p s P G D P_{t}+\lambda_{2} \log B s D c P G D P_{t}+\lambda_{3} \log F D I_{t}+\lambda_{4} \log G f c f_{t}+\lambda_{5} \log T v s t_{t}+\lambda_{6} \log T o r_{t}+v_{t}$

The purpose of transforming the equation 2 is to obtain residuals that are approximately symmetrically distributed because the spread of the residuals changes systematically with the values of the dependent variable.

\section{Stationary Test:}

\section{Discussion of the Empirical Findings:}

The results shown on table 1 below shows the report statistics of the stationarity (unit root) test on the variables. This is achieved by employing the Augmented Dicker-Fuller (ADF) test statistic.

Table 1: Augmented Dicker-fuller Statistic Result:

\begin{tabular}{|c|c|c|c|c|c|c|}
\hline \multirow[t]{2}{*}{ Variables } & \multirow[t]{2}{*}{ ADF Statistic. } & \multicolumn{3}{|c|}{ Critical Value } & \multirow{2}{*}{$\begin{array}{l}\text { Trend \& } \\
\text { Intercept }\end{array}$} & \multirow{2}{*}{$\begin{array}{l}\text { Order of } \\
\text { integration }\end{array}$} \\
\hline & & $1 \%$ & $5 \%$ & $10 \%$ & & \\
\hline Log(GDPPCAP) & -4.201733 & -2.5838 & -1.9428 & -1.6172 & No & $1 \sim 1(1)$ \\
\hline Log(DCTPSPGDP) & -3.444095 & -2.5838 & -1.9428 & -1.6172 & No & $1 \sim 1(1)$ \\
\hline $\log ($ BSDCPGDP) & -4.084577 & -2.5838 & -1.9428 & -1.6172 & No & $1 \sim 1(1)$ \\
\hline $\log (\mathrm{FDI})$ & -4.389651 & -2.5838 & -1.9428 & -1.6172 & No & $1 \sim 1(1)$ \\
\hline $\log (\mathrm{GFCF})$ & -2.638267 & -2.5838 & -1.9428 & -1.6172 & No & $1 \sim 1(1)$ \\
\hline Log(TVST) & -3.924818 & -2.5838 & -1.9428 & -1.6172 & No & $1 \sim 1(1)$ \\
\hline $\log (\mathrm{TOR})$ & -5.206768 & -2.5838 & -1.9428 & -1.6172 & No & $1 \sim 1(1)$ \\
\hline
\end{tabular}

The results in Table 1above shows that all variables are integrated of the same order. It also shows that the variables are stationary at $1 \%, 5 \%$ and $10 \%$ critical value. However, the suspected cointegration problem was corrected by error correction test which is insignificant.

To ascertain the direction of causality between financial sector reform and economic growth, we employed Granger causality test shown on table 2 below.

Table 2: Summary of Granger Causality Test Results:

\begin{tabular}{|l|c|c|}
\hline Null Hypothesis & F-Statistics & Probability \\
\hline LOG_DCTPSPGDP does not Granger Cause LOG_GDPPCAP & 0.18386 & 0.8323 \\
LOG_GDPPCAP does not Granger Cause LOG_DCTPSPGDP & 36.8570 & 0.0000 \\
\hline LOG_BSDCPGDP does not Granger Cause LOG_GDPPCAP & 7.63743 & 0.0008 \\
LOG_GDPPCAP does not Granger Cause LOG_BSDCPGDP & 12.5207 & 0.0000 \\
\hline LOG_FDI does not Granger Cause LOG_GDPPCAP & 11.3723 & 0.0000 \\
LOG_GDPPCAP does not Granger Cause LOG_FDI & 2.84547 & 0.0623 \\
\hline
\end{tabular}

Note: The results on the table 2 above shows only the granger causality test result of the measures of financial sector reforms and economic growth since the aim of the study is to establish the direction of causality between them. 
Out of the three measures of financial sector reforms such as domestic credit to the private sector (DctpsPGDP) as \% of GDP, banking sector domestic credit (bsdcpgdp) as \% of GDP and capital flow proxied with foreign direct investment (FDI), there exist a bidirectional causality between banking sector domestic credit and economic growth proxied with GDP per capita. However, we observed a unidirectional causation running from GDP per capita to domestic credit to the private sector. Also, our result indicated that foreign direct investment granger causes GDP per capita. These suggest that authorities should give priority to policy reforms that will promote the growth in the banking sector or GDP per capita for sustainable development. We Further investigate the influence of market liquidity (proxy; value of shares traded - Tvst and turnover ratio - Tor) and business environment (proxy; gross fixed capital formation - Gfcf) on economic development (proxy - GDP per capita) in Nigeria.

From the investigation, we found a bidirectional causality between total values of shares traded (Tvst) and GDP per capita while GDP per capita cause turnover ratio (TOR). Also the result shows that business environment and economic growth has a strong bidirectional relationship. This indicates that policies aim at improving business environment like strengthening property right, shareholder protection, legal system, security, infrastructural facilities and macroeconomic stability etc in Nigeria, should promotes growth of GDP per capita.

To investigate if financial sector reform promote economic growth in Nigeria, we regress the measures of financial sector reforms, such as ratio of domestic credit to the private sector (DctpsPGDP), ratio of banking sector domestic credit (bsdcpgdp) and capital flow proxied with foreign direct investment (FDI), alongside the measures of market liquidity and business environment on economic growth (GDP per capita) but with particular emphasis on the impact of financial sector reforms measures on growth. Thus, the result is presented on Table 3 below.

Table 3: Estimated Results:

\begin{tabular}{|c|r|r|r|r|}
\hline Variable & Coefficient & Std. Error & t-Statistic & Prob. \\
\hline LOG_DCTPSPGDP & 0.459688 & 0.076457 & 6.012395 & 0.0000 \\
\hline LOG_BSDCPGDP & -0.131635 & 0.048611 & -2.707908 & 0.0078 \\
\hline LOG_FDI & 0.051907 & 0.014948 & 3.472477 & 0.0007 \\
\hline LOG_GFCF & 0.136766 & 0.034310 & 3.986159 & 0.0001 \\
\hline LOG_TVST & -0.136228 & 0.028328 & -4.808917 & 0.0000 \\
\hline LOG_TOR & 0.073498 & 0.037830 & 1.942884 & 0.0545 \\
\hline C & 9.028452 & 0.291950 & 30.92465 & 0.0000 \\
\hline
\end{tabular}

Note: Our interest is on the measures of financial sector reforms.

$\mathrm{R}-$ Square $=0.634488 ; \mathrm{R}-$ Adjusted $=0.615080 ; \mathrm{F}-$ Statistics $=32.69255$ and Durbin - Watson Stat $=1.573352$

The results in table 3 show that all the variables a statistically significant except turnover ratio (Tor). However, the measures of financial sector reforms such domestic credit to the private sector (DctpsPGDP) as \% of GDP and capital flow proxied with foreign direct investment (FDI) have positive impact on economic growth (GDPPCAP) while banking sector domestic credit (BsdcPGDP) as \% of GDP impact negatively on economic growth. The negative impact of credit from the banking sector is amazing. Be that as it may, it could be attributed to high level of corruption in the system, poor legal system for property right protection and high rate of non-performing loan due to lack of proper supervision. The explanatory variables account for approximately 63.45 percent variation in economic growth. The F-Statistic (32.69) indicates that the explanatory variables are jointly significant and are capable of explaining changes in economic growth. Since two measures of financial sector reforms out of three impacts positively on economic growth, we therefore conclude that financial sector reforms promote economic growth, hence rejecting the null hypothesis which stated that financial sector reforms does not promote economic growth in Nigeria. Thus, our findings supported the work of Adelakun (2010) and Ogujiuba and Obiechina (2010).

\section{Summary, conclusion and policy suggestions:}

Given the empirical results reported above, financial sector reform promotes economic growth. This implies that policy reforms targeted on developing the financial sector could promotes the private sector economy via the increase in the domestic credit to private sector (DctpsPGDP) and foreign direct investment which in turn increases the per capita GDP, transforming to economic growth. Our results also proof the relevance of business environment (proxy: Gross fixed capital formation - GFCF) in promoting economic growth. Therefore, friendly business environment is one of the preconditions for growth of the Nigerian economy. Furthermore, the negative impact of total values of share traded as a measured of market liquidity on 
economic growth may be due to the high transaction costs, information asymmetry and lack of confidence in the market.

The granger causality test reported above suggests bidirectional causality between banking sector domestic credit (BsdcPGDP) and economic growth (GDP per capita). This implies that economic growth and growth in the banking sector granger cause each other. Therefore policies targeted at promoting either GDP per capita or banking sector could spur economic growth in Nigeria. A unidirectional causation running from GDP per capita to domestic credit to the private sector (DctpsPGDP) implies that economic growth encourages the demand for credit in the private sector. This in turn increases investment level in the economy thereby reducing the unemployment rate. Also, foreign direct investment granger causes GDP per capita. This suggests that any policy relevance targeted on promoting inflow of FDI into the Nigeria economy would also result to growth in GDP per capita. However, our findings suggest that the major policy variables that can adjusted for growth and development of the Nigerian economy are banking sector domestic credit (BsdcPGDP) and capital flow proxied with foreign direct investment (FDI). Therefore, any policy initiatives aim at promoting the banking sector development and the inflow of FDI will encourage the development of the financial sector and economic growth in Nigeria.

In addition, the development of the Nigerian financial sector is partly dependent on the improvement of business environment such as infrastructural facilities like road, power and telecommunication. Therefore, an enabling business environment and strong legal framework for property right protection needs to be instituted. This to greater extent will promote the level confidence in the market. Also the bidirectional relationship between the banking sector domestic credit and per capita GDP shows that banking sector development or GDP per capita growth could play a significant role in economic growth. Therefore, policies such as bank consolidation, non-interest banking system, and private sector development (e.g. entrepreneurial development programme with proper funding) should be strengthened. Therefore, we recommend that government should fashion sound policies such as tax holiday to encourage inflow foreign domestic investment. This is because, our result suggest a strong granger causality running from FDI to GDP per capita. In addition, government should list more companies with Nigeria stock exchange to increase the total number of shares traded and turnover ratio. Finally, government should also look into the issue of tax holiday and removal of other stringent conditions that may discourage credit to the private sector either from banking sector or other financial institutions like micro finance institutions in the country.

\section{Acknowledgement}

The authors of this research paper are grateful to Peer reviewers of the paper presented at the 201310 th African Finance Journal conference in Durban, South Africa (15-16 May 2013).

\section{Reference}

[1]. Adegbite, Esther O (2005), "Financial Sector Reforms and Economic Development in Nigeria: The Role of Management" A Paper Delivered at the Inaugural National Conference of the Academy of Management Nigeria, Rock view Hotel, Abuja.

[2]. Adelakun, O. J. (2010), "Financial Sector Development and Economic Growth in Nigeria" International Journal of Economic Development Research and Investment Vol. 1, No 1.

[3]. Afangideh, U. J (2009) "Financial Development and Agricultural Investment in Nigeria: Historical Simulation Approach" West African Journal of Economic and Monetary Integration Vol. 9.

[4]. Agu, C.C. and J.O. Chukwu (2008) "Toda and Yamamoto causality tests between "bank based" financial deepening and economic growth in Nigeria". European Journal of Social Science, 7(2), pp.189-98.

[5]. Agu, D. O and Manasseh, O.C (2012), "Financial Crisis, Firm Fundamentals and the Pricing of Bank Stocks in Nigeria - Analysis from a Panel of Banks" A paper presented at the $17^{\text {th }}$ Annual Conference of African Econometric Society, Imperial Royale Hotel, Kampala, Uganda.

[6]. Ahmad, (2012), "Making Pension Contributions Efficient" ThisDay, July $3{ }^{\text {rd }}$ 2012. Link; http://www.thisdaylive.com/articles/making-pension-contributions-efficient/119194/

[7]. Akinlo, Anthony enisan and egbetunde, tajudeen (2010), "financial development and economic growth: the experience of 10 subsaharan African countries revisited" The Review of Finance and Banking Volume 02, Issue 1, Year 2010, Pages 017-028

[8]. Bencivenga, V.R. and B.D Smith. (1991). "Financial Intermediation and Endogenous Growth". Review of Economic Studies, 58(2):403-44

[9]. Boopen Seetanah, Rojid Sawkut, Vinesh Sannasee and Binesh Seetanah (Nil), "Stock Market Development and Economic Growth in Developing countries: Evidence from Panel VAR framework" University of Mauritius, Reduit, Mauritius. http://www.csae.ox.ac.uk/conferences/2010-EDiA/papers/041-Seetanah.pdf.

[10]. CBN (2009), "Financial Sector National Technical Working Group". Vision 2020 report

[11]. Creane S., Goyal, A. Mushfiq M., and Sab R. (2003), "Financial development and growth in the Middle East and North Africa" IMF Working Paper, Washington,DC.

[12]. Dawson, P.J. (2008). "Financial development and economic growth in developing countries." Progress in Development Studies (8) 4, 325-31.

[13]. Gelb, A., (1989). “Cross-section Analysis of Financial Policies, Efficiency and Growth.” Staff working Paper series, WPS 202 (Washington; World Bank).

[14]. Greenwood, J. and B. Jovanovic. (1990). "Financial development, growth and the distribution of income". Journal of Political Economy. 98(5): 1076- 1107. 
[15]. Gunu and Tsado (2012), "Contributory Pension System as a Tool for Economic Growth in Nigeria" International Journal of Business and Behavioral Sciences Vol. 2, No.8

[16]. Gurley. J. G and E.S. Shaw (1960). "Money in Theory of Finance" Washington Brookings Institutes.

[17]. Hicks, John (1969), "A Theory of Economic History”. Oxford; Clarendon Press,

[18]. Hossain, MD. Sharif and. Kamal, Mostafa Khnd. MD (2010), "Does Stock Market Development cause Economic Growth? a time series analysis for Bangladesh Economy" International Conference On Applied Economics

[19]. Joseph Stiglitz (1994), "The Role of the State in Financial Markets", Proceedings of the World Bank Annual Conference on Development Economics,

[20]. Kama U (2006). "Recent Reforms in the Nigerian Banking Industry: Issues and Challenges". CBN Bullion, 30: 3.

[21]. King, Robert G., and Ross Levine, (1993), "Finance and Growth: Schumpeter Might Be Right", Quarterly Journal of Economics $108,717-738$.

[22]. Levine R. and Zervos S. (1998). "Stock Markets, Banks, and Economic Growth.” The American Economic Review, (88) 3, June.

[23]. Levine, R. (1998), "Financial Development and Economic Growth; Views and Agenda, Journal of Economic Literature, Vol.35, pp.31-77

[24]. Levine, Ross, (2004). Finance and growth: theory and evidence: NBER Working Paper Series n.10766. Harvard University Press.

[25]. Majid, M.S.A. (2007). "Re-Examining the Finance-Growth Nexus: Empirical Evidence from Indonesia." Gadjah Mad International Journal of Business, (9) 2, 137-156.

[26]. Manasseh,O.C; Asogwa,F.O and Agu,D.O (2012), "The Causality Effect of Stock Market Development, Financial Sector Reforms and Economic Growth in Nigeria; the Application of Vector Autoregressive (VAR) and Vector Error Correction Model (VECM)" A Paper presented at the Global Development Finance Conference. Crystal Towers, Century City, Cape Town, South Africa.

[27]. Mazur, E.M.and Alexander R. (2001). "Financial Sector Development and Economic Growth in New Zealand." Applied Economics Letter, 8, 545-549.

[28]. Mckinnon R.I. (1973). "Money and Capital in Economic Development.” Washington, D.C. Brookings Institution

[29]. Ndebbio, J.E. (2004). "Financial deepening, economic growth and development: Evidence from selected sub-Saharan African Countries". Research Paper 142 African Economic Research Consortiums, Nairobi, Kenya, August.

[30]. Nzotta, S.M and E. J. Okereke (2009) "Financial deepening and economic development of Nigeria: An Empirical Investigation" African Journal of Accounting, Economics, Finance and Banking Research Vol. 5

[31]. Odeniran S.O. and Udeaja E.A. (2010), "Financial Sector Development and Economic Growth: Empirical Evidence from Nigeria" Central Bank of Nigeria Economic and Financial Review Volume 48/3

[32]. Odhiambo, N.M. (2005). "Financial Development and Economic Growth in Tanzania: A Dynamic Causality Test". Africa Finance Journal, (7) Part 1, 1-17.

[33]. Ogujiuba and Obiechina (2011), "Financial Sector Reforms in Nigeria: Issues and Challenges" International Journal of Business and Management Vol. 6, No. 6

[34]. Sanusi Lamido (2012), "Banking Reform and its impact on the Nigerian Economy" Being lecture delivered at the University of Warwick's Economic Summit, UK 17th February.

[35]. Schumpeter J., (1912), "The Theory of Economic Development". Oxford University Press, Oxford

[36]. Schumpeter, Joseph (1912). "The Theory of Economic Development, Cambridge, Mass

[37]. Shaw, E. S. (1973). "Financial Deepening In Economic Development." Oxford University press, New York.

[38]. Singh, A. (1999), "Financial Liberalization, Stock - Markets and Economic Development", Economic Journal, 107(2), 771 - 782

[39]. World Bank Economic Review and World Bank Research Observer, 1, 19-62. 